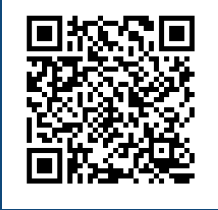

Keywords: Dominant height Forestry Site quality

Historic: Received 04/12/2018 Accepted 22/04/2019

+Correspondence: senilliani@yahoo.com.ar
Maria Gracia Senillianila+, Cecilia Bruno², Miguel Brassiolo'

\section{SITE INDEX FOR PROSOPIS ALBA PLANTATIONS IN THE SEMI-ARID CHACO THROUGH MIXED MODELS}

SENILLIANI, M. G.; BRUNO, C.; BRASSIOLO, M. Site index for Prosopis alba plantations in the semi-arid chaco through mixed models. CERNE, v. 25, n. 2, p. 195-202, 2019.

\section{HIGHLIGHTS}

The SI for Prosopis alba Griseb is presented from anamorphic curves at the Eb of I5 years.

The pattern of evolution in height is adjusted to the Gompertz model.

In the study area, the species culminates its growth in height, close to 20 years.

Nonlinear mixed models have better fit than linear and nonlinear models of fixed effects.

\section{ABSTRACT}

The classification of sites through curves of Site Index allows to predict the yield of the planted forests at a certain age of the stand and to plan cultural treatments. The goal of this research was to compare linear and non-linear models of fixed effects vs. mixed non-linear models to estimate the site index in plantations of Prosopis alba var Griseb in the irrigated area of the province of Santiago del Estero, Argentina using the guide curve method. The data used comes from temporary plots, permanent plots and growth data from the stem analysis of selected individuals based on their greater growth in height within the sampled areas. The registered variable for the evaluation of the site was the dominant Height (HD), defined as the average height of the 100 thickest trees per hectare. Considering that the source of data from repeated measurements on the same subject implies the presence of correlation and/or heteroscedasticity, it was proposed to evaluate statistical models that allow to properly representing the structure of the variance-covariance matrix, improving the accuracy in the adjustment. From the analysis of the results, it appears that the models non-linear mixed models have had better performance in the adjustment of the Site Index than linear and non-linear models of fixed effects. The most accurate model (smallest AIC and BIC) in the site index estimation was the mixed non-linear regression model of "Gompertz", with structure of composite symmetry correlation and exponential heteroscedasticity. 


\section{INTRODUCTION}

In forestry the term site is used to designate the influence of the environment on the production of a good or service of the forest, be it wood, fodder or fruit. The quality of the site is the response in the development of a certain species to the totality of the environmental conditions existing in a certain place (Prodan, 1997). In forest plantations whose purpose is logging, the quality of the site is defined as its potential for the production of wood of a species or a type of forest, considering that better qualities will have a higher production (Clutter et al., 1983).

With respect to the Prosopis alba species, multiple studies of the genus Prosopis highlight its importance as a fundamental resource for semi-arid zones of the region. It is suggested that species of the genus Prosopis have the potential to be used in the restoration of degraded areas mainly under saline conditions (Taleisnik and López Launestein, 20II, Salto et al., 2016). Among the outstanding species, Prosopis alba presents both direct and indirect benefits, it is a multipurpose species for forage, human food, firewood, coal, wood and the importance of the role in the recovery of saline areas is recognized.

The classification of the sites for the Prosopis alba Griseb species in forest plantations, according to quality is of importance since it allows to predict the yield of the forest masses at a certain age of the stand.

According to Skovsgaard and Vanclay (2008); Cosenza et al., (2017), the methods for assessing the productivity of a site can be divided into dendrocentric and geocentric, the first based on information from the stands themselves and the second using environmental variables related to the site.

Within dendrocentric methods, we can name the Dasometric Site Index (SI), as the one that indirectly estimates the volume through a variable closely related to it, such as the dominant height of a stand (Clutter et al., 1983). The site index is the variable able to predict the amount of wood to be produced in a particular site with greater accuracy than any other variable because the density of the stand (Clutter et al., 1983) less influences it. Then, the term Site index is defined as the numerical value of the HD of a stand at a certain age, called the base age (Eb) (Prodan, 1997) and is considered an expression of site quality. In the present work, the HD definition will be used as the average height of the 100 thickest trees per hectare (Assmann's dominant height).

In this context, the estimation of the parameters of the models has traditionally been made with linear and non-linear regression models of fixed effects that assume normality, equality of variances (homocedastic) and independence of the residuals (Draper Smith, 1981). This situation does not always conform to the nature of the data, which have a structure of longitudinal data because the observations are taken repeatedly on the same observational unit. In this case, the structure of the matrix of variances and covariances of the residuals does not correspond to the assumptions of the classical linear models (General Linear Models), since it is not possible to randomize the temporal or spatial factor, violating the assumption of independence of the errors. Heteroscedasticity can also be observed in the heightage relationship over time (Jerez Rico et al., 20I I). Given this situation, the Mixed Linear Models (MLM) and the Non-Linear Mixed Models are an alternative to achieve greater precision (West et al., 2006).

The goal in the present research is define the Site Index for the Prosopis alba Griseb species in forest plantations, evaluating the relative performance and precision of linear and non-linear models, with fixed effects and mixed effects to represent site index curves. Once the most appropriate model is defined, a family of anamorphic site index curves will be generated.

\section{MATERIAL AND METHODS}

\section{Characterization of the study area}

The province of Santiago del Estero, located within the subregion of the semi-arid Chaco of the Argentine Republic, is located between $25^{\circ} 35^{\prime}$ and $30^{\circ}$ $4 I^{\prime}$ South latitude and between $61^{\circ} 34^{\prime}$ and $65^{\circ} 34^{\prime}$ 'West longitude. The average annual rainfall is $300-500 \mathrm{~mm}$ in the centre of the region. They are concentrated in the summer and early autumn (Kunst et al., 20I I).The work zone was included within the Dulce River irrigation area in the province of Santiago del Estero, at a latitude of $27^{\circ} 39^{\prime}$ South and longitude W $64^{\circ}$ I4', covering approximately 110,000 hectares with a general area of influence of 275,365 hectares.

\section{Inclusion criteria and evaluated variables}

The criteria for the selection of the sites have been based on the selection of plantations of ages older than or equal to 9 years of age. i.e., that have passed their initial stage or juvenile growth and have been established in different soil qualities, to ensure homogeneity in the genetic material of the species and have received minimal silvicultural interventions (early pruning and weeding). The quality of soils was evaluated according to the chemical and physical properties of the soils. At each site, a variable number of plots were established 
based on the height variability of the stand, taking as a criterion that the coefficient of variation did not exceed $20 \%$. The data used in this work come from temporary plots, permanent plots and stem analyses of dominant individuals within the sampled areas. The stem analyses was performed on a sample of 15 individuals of Prosopis alba were cut for destructive sampling. Wood slices were extracted from the harvested trees at $0.30 \mathrm{~m}, 1.30 \mathrm{~m}$, $2.00 \mathrm{~m}, 3.00 \mathrm{~m}$, to the tree apex following the main stem. Northern aspect of each slice was identified for the measurements at laboratory. Prior to counting and measurement of growth tree-rings, we proceeded to sanding the slices (Beltran et al., 2016). The samples, once prepared, were digitally marked with an HP Scanjet G24I0 scanner, at a resolution of $1200 \mathrm{dpi}$ and the measurement of the growth rings was made using Image Pro Plus software version 4.5.

The registered variable for the evaluation of the site is the dominant height (HD), measured with a telescopic rod. The base age or reference age set to determine the site index is 15 years, considering that it could represent half of the turn for the species, meaning, "turn" as the time necessary for the forest use of the plantation.

Twelve sites were sampled in Robles, La Banda, Colonia and San Martin localities (Figure I); seven of them are considered temporary plots (PT) and the rest permanent (PP). The surface of the sample sites comprises between half a hectare and 50 hectares. The age of the trees ranges between 9 and 26 years. The spacing between trees varies according to the plantation setting and the management of each site. Table I describes the sites sampled in terms of their area, age, spacing, type and number of plots as well as the number of measurements made in each one.

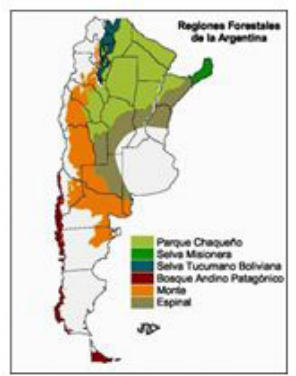

TABLE I Descriptive statistics of the data groups.

\begin{tabular}{ccccccc}
\hline $\begin{array}{c}\text { Local Place } \\
\text { name }\end{array}$ & $\begin{array}{c}\text { Area } \\
\text { (ha) }\end{array}$ & $\begin{array}{c}\text { Age } \\
\text { (years) }\end{array}$ & $\begin{array}{c}\text { Spacing } \\
\text { between } \\
\text { trees }\end{array}$ & $\begin{array}{c}\text { Type of } \\
\text { plot }\end{array}$ & $\begin{array}{c}\text { Number } \\
\text { of plots } \\
\text { evaluated/ } \\
\text { site }\end{array}$ & $\begin{array}{c}\text { Number } \\
\text { of } \\
\text { measurements/ } \\
\text { plot }\end{array}$ \\
\hline Robles & 3 & 15 & $6 \times 2$ & PP & 3 & 4 \\
Robles & 40 & 11 & $4 \times 3$ & PT & I & 2 \\
Robles & I & 15 & $4 \times 5$ & PT & I & 2 \\
Robles & 50 & 16 & $5 \times 4$ & PP & 4 & 2 \\
Robles & 0.75 & 18 & $6 \times 3$ & PP & 2 & 4 \\
Robles & 0.5 & 18 & $4 \times 4$ & PP & 2 & 2 \\
San Martin & 0.5 & 26 & $6 \times 6$ & PP & 1 & 3 \\
La Banda & 3 & 16 & $5 \times 3$ & PP & 2 & 4 \\
San Martin & I & 20 & $3.5 \times 3.5$ & PP & I & 3 \\
Robles & 10 & 11 & $2 \times 8$ & PT & 1 & 1 \\
La Banda & 3 & 9 & $2 \times 8$ & PT & 2 & 1 \\
Colonia S & 6 & 9 & $4 \times 4$ & PT & 6 & 1 \\
\hline
\end{tabular}

PT: temporary plot PP: permanent plot

\section{Modeling of Site Index curves}

Studies on growth in trees (e.g. Amico et al., 2010, Beltran et al., 2015) obtained growth curves using the following model, where, $y=$ vector of observations (dependent variable), $\int($ ) represents a linear or nonlinear function in the parameters, $X=$ design matrix (independent variables), $\theta=$ vector of parameters of fixed effects and $\varepsilon=$ vector of errors. That are assumed with normal and independent distribution with mean of 0 and matrix of constant variances $\sum$ (Jerez Rico et al., 20I I, Draper and Smith, 198I).

$y=\int(X, \theta, \varepsilon)$

When measurements are made on permanent plots (PP) or stem analyses, non-independent (correlated) observations are generated. The structure of the residuals variance-covariance matrix does not meet the assumptions of classical regression models likewise; the variability between individuals can cause heteroscedasticity. Mixed models enable us to

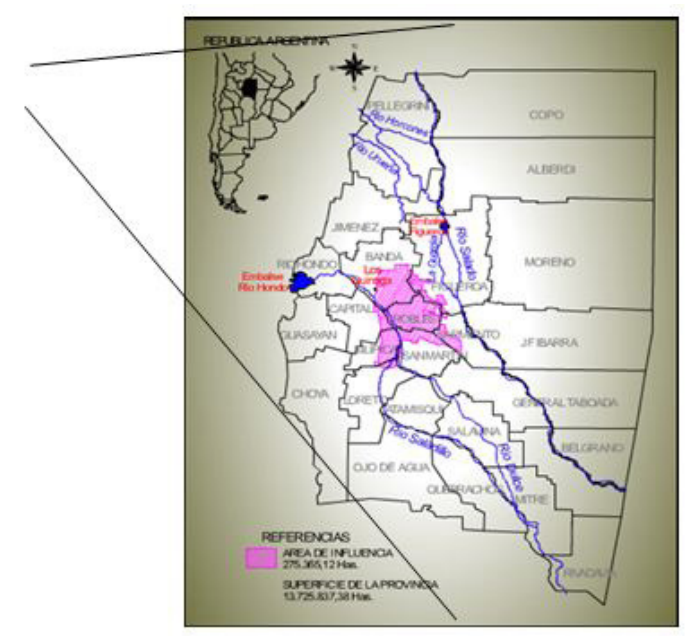

FIGURE I Map of the Province of Santiago del Estero, located within the Chaqueña region of the Argentine Republic. Forest regions of Argentina. Secretary of Environment of the Nation. 
appropriately represent the structure of the variancecovariance (Jerez Rico et al., 20 I I). The mixed model can be described by adding a random effects vector as follows, where, $y=$ vector of observations (dependent variable), $\int=$ linear or non-linear function in the parameters, $X=$ design matrix (independent variables), $\theta$, vector of fixed-effect parameters, $b=$ vector of random effects modeling the heterogeneity between subjects and the correlation between them and $\varepsilon=$ error vector.

$y=\int(X, \theta, b, \varepsilon)$

Nine models were evaluated to describe growth patterns in dominant height (HD) in relation to age in forest stands. A second-order linear model with independent and homocedastic errors and 4 non-linear models: Chapman-Richards, Gompertz in its differential form (Domínguez-Calleros et al., 2017), Monomolecular and Logistic with structure of correlation of errors and for heterogeneous variances (Table 2).

The method of the guide curve was used, which consists of obtaining a standard curve for a reference age ( 15 years) from the growth model called the Site Index. The harmonization of this standard curve allows obtaining the family of anamorphic curves (Prodan, 1997). The data were analyzed statistically with InfoStat (Di Rienzo et al., 20।8).

TABLE 2 Descriptive statistics of the data groups. Fitted model Fitted function

2nd degree polynomial $H D=\alpha+\beta x+\gamma x$

Chapman-Richards

$H D=\alpha^{*}\left[1-\operatorname{Exp}\left(-\beta^{*} E\right)\right]$

\begin{tabular}{ccc} 
Gomperzt & $H D=\alpha^{*} \operatorname{Exp}\left[-\beta^{*} \exp \left(-\gamma^{*} E\right)\right]$ \\
\hline Monomolecular & $H D=\alpha^{*}\left(1-\beta^{*} \operatorname{Exp}(-\gamma / E)\right)$ \\
\hline
\end{tabular}

Logistics $\quad H D=\alpha / 1+\operatorname{Exp}(-(E-\beta) / \gamma)$

$\mathrm{HD}=$ Dominant height, $\mathrm{E}=$ age (years), = parameters to be estimated

\section{RESULTS AND DISCUSSION}

It is observed in the Figures 2 and 4 , that the growth process has three stages. An initial stage or juvenile stand ( $<8$ years) where there is a marked increase in HD, then a stage of intermediate ages ( 8 to 15 years) where the increase decreases and the stand reaches the final height towards maturity (older than I5 years). The variability of $H D$ is greater in the stands during the first and second growth stages, i.e. juvenile and intermediate, while, as the age of the same increases, the variability of the HD decreases (CV of $61.5 \%<8$ years, $22.5 \%$ in the stage of 8 to 15 and $12.6 \%>15$ years). The greater variability present at early ages responds to the behaviour of the masses influenced by various factors. For example, genetic variability, planting technique, initial density, fertilization, etc., which interferes mainly with the initial development of trees, creates a more conducive environment for growth until the stand establishes itself (Costa Silva et al., 2017). The average dominant height and the existing variation in the plots grouped according to three age ranges related to the growth process are recorded in Table 3.

TABLE 3 Average dominant height (HD) and variability in relation to the age of the stands standard deviation (DE), minimum and maximum, defined by ranges of early or juvenile ages (from I to 8 years old), middle ages (from 8 to 15 years old) and stands I 5 years older.

\begin{tabular}{cccccc}
\hline $\begin{array}{c}\text { Age } \\
\text { (years) }\end{array}$ & $\begin{array}{c}\text { Number of } \\
\text { Trees }\end{array}$ & $\begin{array}{c}\mathrm{HD} \\
(\mathrm{m})\end{array}$ & $\begin{array}{c}\mathrm{DE} \\
(\mathrm{m})\end{array}$ & $\begin{array}{c}\text { Minimum } \\
(\mathrm{m})\end{array}$ & $\begin{array}{c}\text { Maximum } \\
(\mathrm{m})\end{array}$ \\
\hline I to 8 & 47 & 2.6 & 1.6 & 1.0 & 7.7 \\
8 to 15 & 33 & 7.1 & 1.6 & 3.5 & 9.8 \\
$>15$ & 11 & 8.7 & 1.1 & 7.1 & 10.5 \\
\hline
\end{tabular}

There are numerous site index studies adjusted with the classic statistical models, i.e., models that assume independent, normal and homogeneous distribution of the errors. For example, De Souza Retsalff et al., (20I5), in their research showed that the Site Index curves for Eucalyptus grandis were constructed by the classic model guide-curve method, where the Chapman-Richards model showed the best fit and precision statistics. In Argentina, in the Mesopotamian region, there are numerous growth studies in coniferous and broad-leaved hardwoods. Crechi et al. (20II) conducted a site index study in Eucalyptus grandis, using three traditional methods, the guide curve method, the reparameterization method and differential equations, where the choice of method was based on the quality of the information available in the study areas. However, Jerez Rico et al. (20I I) proposed other approach for the study of site index in the Llanos de Venezuela, studies of site index curves according to mixed models for Tectona grandis, when the structure of the matrix of variances and covariances of the residuals does not correspond to the assumptions of the classical linear models. In agreement with Jerez Rico et al. (20II), this study have found similar findings in the precision of non-linear models, with mixed effects to represent site index curves.

The results suggest that patterns of the dominant height (HD) adjusted with the classic statistical models, i.e., models that assume independent, normal and homogeneous distribution of the errors, presented differences among them (Figure 2a). The polynomial 
model is markedly apart from the general behaviour of the remaining curves, describing a growth that is very far from the observed data. The other curves differ, in a narrow range of $\mathrm{HD}(<\mathrm{Im})$, if the juvenile stage of the stand ( $<8$ years) and the adult stage ( $>15$ years) are observed. The Gompertz model, with an intermediate position with respect to the other models, describes a growth with an ascending rhythm, to decrease progressively afterwards and having an asymptotic behaviour after approximately 20 years.

However, when the correlation was contemplated due to repeated measurements over time, the models showed different behaviours in their adjustments from intermediate ages to adulthood (older than 15 years) (Figure $2 \mathrm{~b})$. In the adjusted growth curves with mixed nonlinear models, the biggest difference was between the ChapmanRichards and monomolecular models (similar to each other) with the Logistic model. During the period between 8 to 15 years, the curves describe a sustained growth with differences in the slope of up to I meter between them, with a higher growth rate of the logistic model, which reaches the maximum height value at approximately 14 years, being in this instance surpassed by the other models, and greatly surpassed by the Chapman-Richards and monomolecular model. In this stage, the difference between the models is $>1 \mathrm{~m}$. The cause of this overestimation of the maximum height that a stand can reach, may be due to the smaller amount of data in higher ages, being more affected the lack of power of the models named. Again, the Gompertz model presents an intermediate positioning with respect to the other models and it is considered that it shows a correct biological representation.

In agreement with other previous studies, Kees et al. (20/8) determined growth models for Prosopis alba Griseb plantations in the humid Chaco region from the Gompertz model considering that it correctly assembles the biological aspects of growth of the tree stands. Likewise, the author estimates that the species culminates its growth in height around 25 years, unlike the plantations in the study region that report decreases in the growth rate in height from about 20 years.

The application of mixed models allowed us to model the correlation structure of errors and heteroscedasticity from measures repeated over time (West et al., 2006). The parameters estimated with the models and their standard error are presented in Table 4. Of all the models, the model 3 adjusted under independent errors and homogeneous variances presented approximate values with respect to the model 7 adjusted with exponential variance function, with slightly smaller standard errors in Model 7. The other models show greater variations in their parameters and errors depending on whether they are fixed or mixed effects models.

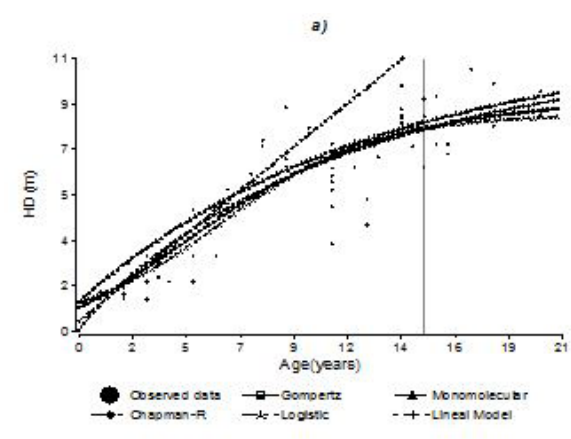

b)

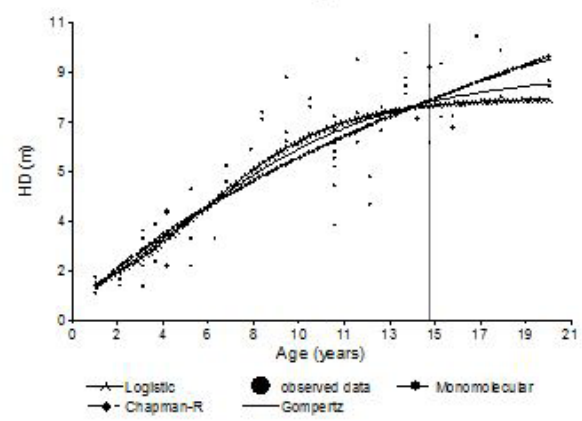

FIGURE 2 Growth curves measured through the dominant height (HD) according to the age measured in years. a) Classical nonlinear models Gompertz, Monomolecular, Chapman Richards, Logistic, and Second-order polynomial linear model, b) Nonlinear mixed models for Logistic, Monomolecular, Chapman Richards and Gompertz.

To evaluate the fit of the models, the Akaike information criterion (AIC), the Schwartz Bayes information criterion (BIC) and the standard error in the parameters were used, indicating that the lower the value the higher the adjustment. In order to be able to compare the fit of classical linear and nonlinear models vs. Non-linear mixed models, the goodness of fit criteria for each situation is described below. It is observed that the best-fit are obtained with the Monomolecular model, adjusted with fixed effects (classic model). When the effect of modelling the correlation and the heterogeneous variance is incorporated, the best-fit model is Gompertz, reporting a lower residual variance to the others (Table 5 and 6).

The residuals analyses (Figure 3 ) indicates that in most models there is a lack of homogeneity in the variance and that it was corrected with the mixed model. The presence of a pattern in the residues of most classic models evidencing heteroscedasticity is notable, with significant values through the Levene test. According to the results of this study, Jerez Rico et al. (2008), states that growth models in height are characterized by an increase in the variance of errors with age, generating deficiencies in the accuracy and predictability of models adjusted under classical assumptions. 
TABLE 4 Estimated parameters their standard errors for each of the 9 fitted models of growth curve in dominant height as a function of the age of carob plantations in the semi-arid Chaco region. Models I to 5 fixed effects, independent errors, homocedastic. Models 6 to 9 with correlation and heteroscedasticity..

\begin{tabular}{|c|c|c|c|c|c|c|c|c|c|c|}
\hline \multicolumn{2}{|r|}{ Fitted models } & \multicolumn{3}{|c|}{$\alpha$} & \multicolumn{3}{|c|}{$\beta$} & \multicolumn{3}{|c|}{$\gamma$} \\
\hline $\mathrm{I}$ & Lineal model & 0.3 & \pm & 0.3 & 0.7 & \pm & 0.08 & -0.02 & \pm & $3.2 \times 10.3$ \\
\hline 2 & Chapman-Richards & 11.2 & \pm & 1.9 & 0.08 & \pm & 0.04 & 0.9 & \pm & 0.17 \\
\hline 3 & Gompertz & 9.3 & \pm & 0.6 & 2.3 & \pm & 0.2 & 0.1 & \pm & 0.03 \\
\hline 4 & Monomolecular & 11.5 & \pm & 1.6 & 0.9 & \pm & 0.03 & 0.08 & \pm & 0.02 \\
\hline 5 & Logistics & 8.7 & \pm & 0.4 & 6.2 & \pm & 0.5 & 3.3 & \pm & 0.4 \\
\hline 6 & $\begin{array}{l}\text { Chapman-Richards (Correlation Symmetry compound and function of } \\
\text { exponential variance) }\end{array}$ & 23.6 & \pm & 28 & 0.02 & \pm & 0.04 & 0.7 & \pm & 0.09 \\
\hline 7 & $\begin{array}{c}\text { Gompertz } \\
\text { (Compound symmetry correlation and power variance function) }\end{array}$ & 9.1 & \pm & 0.5 & 2.3 & \pm & 0.07 & 0.2 & \pm & 0.02 \\
\hline 8 & $\begin{array}{l}\text { Monomolecular (correlation Symmetry Composite and power variance } \\
\text { function) }\end{array}$ & 14.6 & \pm & 3.11 & 0.9 & \pm & 0.01 & 0.05 & \pm & 0.02 \\
\hline 9 & $\begin{array}{l}\text { Logistics } \\
\text { (Compound symmetry correlation and power variance function). }\end{array}$ & 8.1 & \pm & 0.3 & 5.5 & \pm & 0.37 & 2.7 & \pm & 0.2 \\
\hline
\end{tabular}

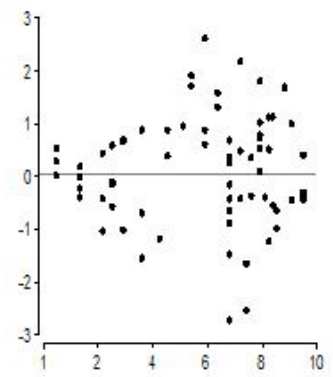

A

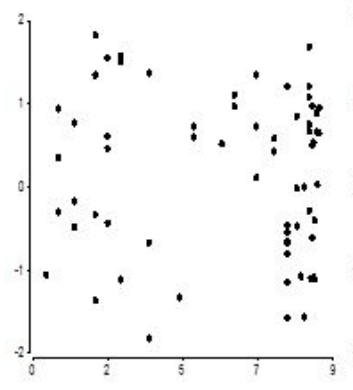

E

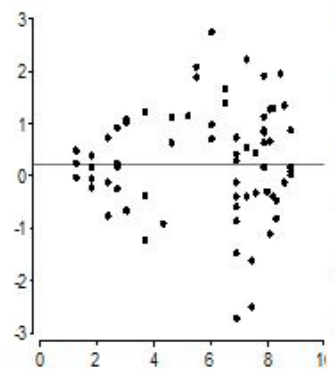

B

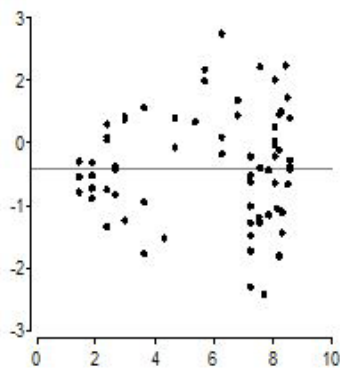

C

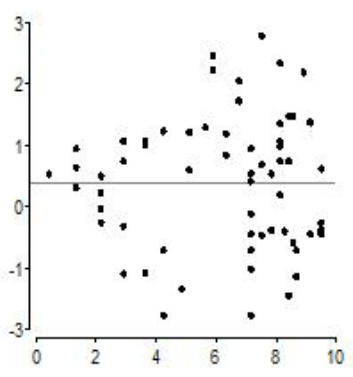

D

FIGURE 3 Studentized residues vs. predicted from classical nonlinear models (above), Gompertz Model (A), Logistic Model (B), Chapman-R Model (C), Monomolecular Model (D) and mixed non-linear models with correction by correlation and heteroscedasticity (below); Gompertz Model (E), Logistic Model (F), Chapman Model (G) and Monomolecular Model (H).

According to the graphic analysis of the fidelity with which the estimated values are adjusted to the real data, the goodness-of-fit parameters and the standard error of the parameters, the model indicated is the mix non-linear Regression Model of "Gompertz", with correlation by compound symmetry and variance of the errors with function of exponential variance. The estimated parameters in the function were highly significant $(\mathrm{p}<.0000 \mathrm{I})$.

From the equation ( $I$ ) and the parameters obtained, IS 8.1 is described using the guide curve method (Figure 4A). When age (E) becomes equal to the Base age ( $E b=15$ years), the dominant height $(\mathrm{HD})$ will be equal to the site index, as shown in Figure 4B.

$$
H D=9.1 * \operatorname{Exp}(-2.3 * \operatorname{Exp}(-0.2 * E))
$$

The family of anamorphic curves is obtained by clearing a (asymptote) in the site index equation by substituting the resulting expression in the original equation; it is considered that the shape and slope parameters are common for all sites. The family of 
TABLE 5 Goodness-of-fit criteria for linear and non-linear models of fixed effects.

\begin{tabular}{|c|c|c|c|c|}
\hline \multirow{2}{*}{$\mathrm{N}^{\circ}$} & \multirow{2}{*}{ Models } & \multicolumn{3}{|c|}{ Linear Regression Model } \\
\hline & & AIC & $\mathrm{BIC}$ & ECMP \\
\hline \multirow{2}{*}{$\mathrm{I}$} & Polynomial 2nd grade & & & \\
\hline & $H D=\alpha+$ & (50) & or & 1.02 \\
\hline & & \multicolumn{3}{|c|}{ Classic Non-Linear Regression Mode } \\
\hline \multirow{3}{*}{2} & Chapman-Richards & & & \\
\hline & & 288.0 & 298.0 & 1.32 \\
\hline & $H D=\alpha^{*}\left[1-\operatorname{Exp}\left(-\beta^{*} E\right)\right]^{*}$ & & & \\
\hline \multirow[b]{2}{*}{3} & Gompertz & & & \\
\hline & $H D=\alpha^{*} \operatorname{Exp}\left[-\beta^{*} \exp \left(-\gamma^{*} E\right)\right]$ & 288.6 & 298.6 & 1.32 \\
\hline \multirow{2}{*}{4} & Monomolecular & 2877 & 2978 & 184 \\
\hline & $H D=\alpha^{*}\left(1-\beta^{*} \operatorname{Exp}(-\gamma / E)\right)$ & & & \\
\hline \multirow{2}{*}{5} & Logístics & 5 & 3015 & 136 \\
\hline & $H D=\alpha / 1+\operatorname{Exp}(-(E-\beta) / \gamma)$ & 201.0 & כ. וסנ & 1.00 \\
\hline
\end{tabular}

anamorphic curves is generated by varying the age, the desired site index for the predetermined Eb (Barreto et al., 20II, Hernández-Ramos et al., 20I5).

The harmonized equation is:

$H D=I S^{*} \operatorname{Exp}\left(-\beta^{*} \operatorname{Exp}\left(-\gamma^{*} E\right)\right) / \operatorname{Exp}\left(-\beta^{*} \operatorname{Exp}\left(\gamma^{*} 15\right)\right)$

Based on the dispersion of the dominant height data obtained at the base age, the equidistance between site index curves of 2 meters between classes is determined.

\section{CONCLUSION}

The productive capacity of the sites for Prosopis alba Griseb is expressed from the family of anamorphic curves at the base age of 15 years, which describe three qualities of site, good, regular and bad, with a height difference of four meters. From a site of higher to lower production. This is a first approximation in the estimation of the site quality of the species, with a recommendation to deepen the study when the database be expanded.

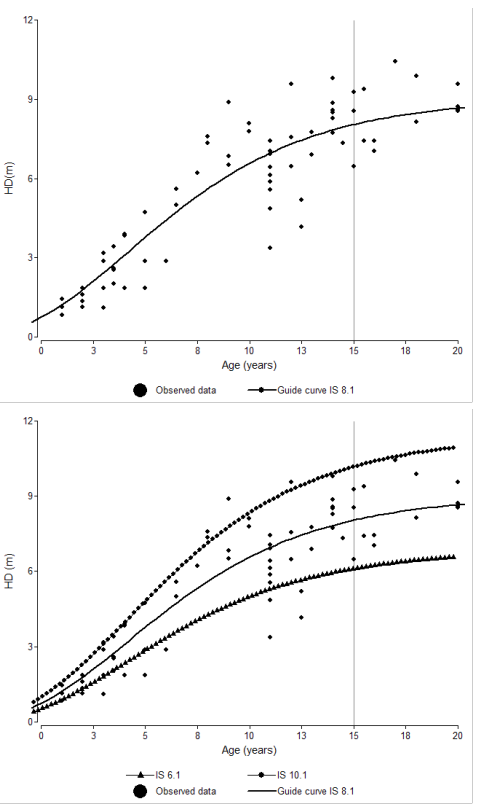

FIGURE 4 A. Determination of the guide curve and B. Family of anamorphic curves.

The pattern of evolution in height is adjusted to the Gompertz model, adapting to the biological growth criteria. The trend shows that the species culminates its growth in height at early ages in the study area, close to 20 years, although this should be corroborated with studies at older ages.

Non-linear mixed models have had better adjustment than classical linear and non-linear models of fixed effects, which is why the estimation of the site index is recommended with the mixed non-linear regression model of Gompertz, with a structure of correlation compound symmetry and variance of the errors with function of exponential variance.

\section{REFERENCES}

AMICO, I.; BAVA, J.; CALDERÓN, A. Índices de calidad de sitio de Populus nigra 'Italica' en plantaciones lineales en el noroeste de Chubut. Revista de la Facultad de Ciencias Agrarias de la Universidad Nacional de Cuyo v. 42, n. I, p. I47-I58, 2010.

TABLE 6 Goodness-of-fit criteria for mixed non-linear models.

\begin{tabular}{|c|c|c|c|c|c|}
\hline \multirow{2}{*}{$\mathrm{N}^{\circ}$} & \multirow{2}{*}{ Models } & \multirow{2}{*}{ Correlation structure and error variance } & \multicolumn{3}{|c|}{ Models Mixed Nonlinear Regression Model } \\
\hline & & & $\mathrm{AIC}$ & $\mathrm{BIC}$ & Var. Residual \\
\hline \multirow[t]{2}{*}{6} & Chapman-Richards & Correlation of compound symmetry and function of exponential variance & 256 & 271 & 0.15 \\
\hline & $H D=\alpha *[1-E x p(-\beta * E)]^{\gamma}$ & & & & \\
\hline \multirow[t]{2}{*}{7} & Gompertz & Correlation of compound symmetry and variance function (Varpower) & 231 & 246 & 0.04 \\
\hline & $H D=\alpha^{*} \operatorname{Exp}\left[-\beta^{*} \exp \left(-\gamma^{*} E\right)\right]$ & & & & \\
\hline 8 & $\begin{array}{c}\text { Monomolecular } \\
H D=\alpha^{*}\left(1-\beta^{*} \operatorname{Exp}(-\gamma / E)\right)\end{array}$ & Correlation compound symmetry and variance function power & 237 & 252 & 0.04 \\
\hline 9 & $\begin{array}{c}\text { Logistics } \\
H D=\alpha / 1+\operatorname{Exp}(-(E-\beta) / \gamma)\end{array}$ & Compound symmetry correlation and variance function (Varpower) & 233.6 & 248.5 & 0.04 \\
\hline
\end{tabular}


BARRERO-MEDEL, H.; MOTHE, F; NEPVEU, G.; ÁLVAREZLAZO, C.; GARCÍA-CORONA, I.; GUERA, M. Curvas anamórficas de índice de sitio para plantaciones de Pinus caribaea Morelet var. caribaea Barret y Golfari de la empresa forestal integral macurije (EFI) en la provincia de Pinar del Río, Cuba. Revista Chapingo, Serie Ciencias Forestales y del Ambiente. v. I7, n.2, p.245-252, 201 I.

BELTRÁN, H.; CHAUCHARD, L.; MARTÍNEZ PASTUR, G. Curvas preliminares de índice de sitio para bosques puros y mixtos de Nothofagus alpina y Nothofagus obliqua en la Patagonia Argentina. Bosque. v. 36, n. 2, p. 275-285, 2015.

BELTRÁN, H.; CHAUCHARD, L.; VELÁSQUEZ, A.; SBRANCIA, R.; MARTÍNEZ PASTUR, G. Diametric site index: an alternative method to estimate site quality in Nothofagus obliqua and N. alpina forests. CERNE. v.22, n.3, p. 345-354, 2016.

CLUTTER, J. L.; FORTSON, J. C.; PIENAAR, L. V.; BRISTER, G.H.; BAILEY, R.L. Timber Management: A Quantitative Approach. New York. 1983. 333 p.

COSENZA, D.; SOARES, A.V.; ALCÂNTARA, A. M.; SILVA, A. A. L; RODE, R.; SOARES, V.; LEITE, H. G. Site classification for eucalypt stands using artificial neural network based on environmental and management features. CERNE, v.23, n.3, p. 310-320, 2017.

SILVA, G. C.; CALEGARIO, N.; SILVA, A. A. L.; PEREIRA DA CRUZA J.; GARCIA LEITE H. Site index curves in thinned and non-thinned eucalyptus stands Forest Ecology and Management, v. 408, p. 36-44, 2018.

CRECHI, E.H.; FASSOLA, H.E.; KELLER, A.E.; BARTH, S.R. Desarrollo de funciones de índice de sitio para Eucalyptus grandis cultivado en la Mesopotamia Argentina. Revista de Investigaciones Agropecuarias, v. 37, n. 3, p. 238248.201 I

RETSLAFF, F. S; FIGUEIREDO FILHO A.; DIAS, A. N.; BERNETT, L. G; FIGURA, M. A. Site index curves and hypsometric relationship for Eucalyptus grandis plantations for the Campos Gerais region, Parana State. CERNE, v.2I, n.2, p.219-225, 2015.

RIENZO, J. D.; CASANOVES, F.; BALZARINI, M.; GONZALEZ, L.; TABLADA, M.; ROBLEDO, C. InfoStat versión 2018. Grupo InfoStat, FCA, Universidad Nacional de Córdoba, Argentina, 2018. URL http://www.infostat.com.ar.

DOMÍNGUEZ-CALLEROS, P.; RODRÍGUEZ-FLORES, F; LIZÁRRAGA-MENDIOLA, L.; JIMÉNEZ-GÓMEZ, M.; NAVAR, J. Aplicaciones y ejemplos de modelos de crecimiento diamétrico para árboles tropicales. Ecosistemas y recursos agropecuarios, v. 4, n. II, p. 265-274, 2017.
DRAPER, N.; SMITH, H. Applied Regression Analysis. 2nd ed. Wiley New York, USA. 198I, 736 pp.

HERNÁNDEZ-RAMOS, J.; GARCÍA-MAGAÑA, J.; GARCÍACUEVAS, X.; HERNÁNDEZ-RAMOS, A.; MUÑOZFLORES, H.; SAMPERIO-JIMÉNEZ, M. Índice de sitio para bosques naturales de Pinus teocote Schlecht. \& Cham en el oriente del estado de Hidalgo. Revista Mexicana de Ciencias Forestales. v.6, n.27, p. 24-37, 2015.

JEREZ-RICO, M.; MORET-BARILLAS, A.; CARRERO-GÁMEZ, O.; MACCHIAVELLI, R.; QUEVEDO-ROJAS, A. Curvas de índice de sitio basadas en modelos mixtos para plantaciones de Teca (Tectona grandis L. F.) en los Llanos de Venezuela. Agrociencia, v.45, n. I, p. I35-145, 201 I.

KEES, S.; FERRERE, P.; LUPI, A.; MICHELA, J.; SKOKO, J. Producción y crecimiento de las plantaciones de Prosopis alba Griseb en la provincia del Chaco, Revista de Investigaciones Agropecuarias. v. 44, n.2, p. II3-120, 2018.

KUNST, C; LEDESMA, R.; BRAVO, S.; DEFOSSÉ, G.; GODOY, J.; NAVARRETE, V. Dinámica de la humedad de los combustibles y su relación con la ecología y manejo de fuego, región chaqueña occidental (Argentina) II: follaje y residuos de árboles y arbustos. Revista de Investigaciones Agropecuarias. v.40, n.2, p. 165-181, 2014.

PRODAN, M.; PETERS, R.; COX, F.; REAL, P. Mensura Forestal. Series. IICA/GTZ. San Jose Costa Rica. 1997. 56 I p.

SALTO, C.; HARRAND, L.; OBERSCHELP, G.; EWENS, M. Crecimiento de plantines de Prosopis alba en diferentes sustratos, contenedores y condiciones de vivero. Bosque, v.37, n.3, p.527-537, 2016.

SAyDS. Secretaria de medioambiente de la Nación. Regiones forestales de la Argentina. Available at: http:// www2.medioambiente.gov.ar/documentos/bosques/ umsef/cartografia/mapa_regiones.pdf. Accessed in: March 18th 2019.

SKOVSGAARD, J.; VANCLAY, J. Forest site productivity: a review of the evolution of dendrometric concepts for even-aged stands. Forestry, v.8I, n. I, p.I3-3I, 2008.

TALEISNIK, E.; LÓPEZ LAUNESTEIN, D. Leñosas perennes para ambientes afectados por salinidad. Una sinopsis de la contribución argentina a este tema. Ecología austral, v.2I, n. I, p.3-14, 2011 .

WEST, B.; WELCH, K.; GALECKI, A. Linear Mixed Models. A Practical guide Using Statistical Software. Second Edition. CRC Press, 2006. 440p. 